\title{
New Route to Pyrido[1,2-b]pyridazinium Inner Salts. Evidence of a 1,3-Dipolar Cycloaddition-Ring Expansion Process
}

\author{
Jesús Valenciano, Ana M. Cuadro, Juan J. Vaquero and \\ Julio Alvarez-Builla* \\ Departamento de Quimica Orgánica. Universidad de Alcalá. \\ 28871-Alcald de Henares, Madrid. Spain \\ Received 4 August 1998; revised 2 October 1998; accepted 10 November 1998
}

\begin{abstract}
:
2-Alkoxycarbonylpyridinium $\mathrm{N}$-aminides behave as 1,3-dipoles when reacted with Michael acceptors, giving rise to the corresponding cycloadducts which, depending on their regioisomeric nature, subsequently undergo a ring expansion to give pyrido[1,2-b]pyridazinium inner salts. $\mathcal{O} 1999$ Elsevier Science Ltd. All rights reserved.
\end{abstract}

Keywords: N-aminides; betaines; rearrangement; 1,3/1,4-dipoles

The heterocyclic mesomeric betaines [1] 1 are well established versatile 1,3-dipoles, which allows them to take part in 1,3-dipolar cycloaddition reactions [2]. 2-Alkyl and 2-amino substituted structures 2 have the potential to function as 1,4-dinucleophiles via deprotonation and are capable of reacting with 1,2-dicarbonyl compounds (Westphal reaction) [3] to give a variety of azonia derivatives possessing a quaternary bridgehead nitrogen [4-11]. By contrast, with the exception of a few examples [12-15] relatively less attention has been paid to the possibility of using ylides 3 as 1,4-nucleophile-electrophiles (Fig. 1).

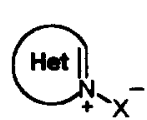

1

$\mathrm{X}=\mathrm{NH}, \mathrm{CHR}$

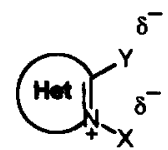

2

$\mathrm{Y}=\mathrm{NH}_{2}, \mathrm{CH}_{2} \mathrm{R}$

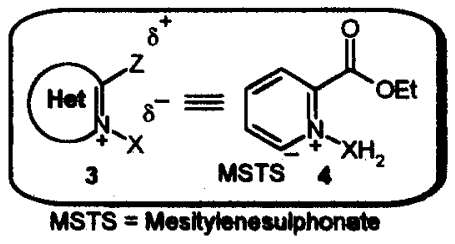

Fig. 1

With regard to the reactivity of 3, we reported in a previous paper [16 ] a few examples of the 1,4-nucleophile-electrophile character of 2-ethoxycarbonyl azinium salts 4 which, on reaction with isocyanates and isothiocyanates gave rise to new conjugated mesomeric betaines 
in a [4+2] cyclocondensation process. It has also been reported however, that the $\mathrm{N}$-aminides 5 , behave as 1,3-dipoles when reacted with ethyl propiolate to afford the corresponding cycloadducts [17] (Scheme 1).

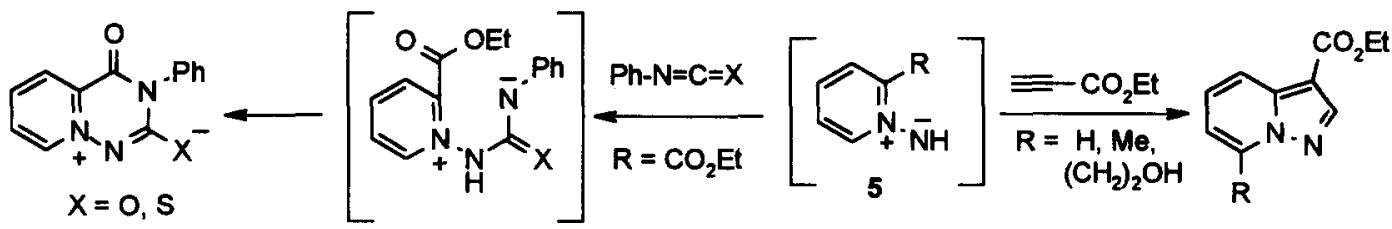

Scheme 1

This apparent dual role, prompted us to explore the reactivity of 4 with different olefinic dipolarophiles in order to gain insight into its behaviour. Initially we reacted $\mathrm{N}$ methylmaleimide with $4(\mathrm{X}=\mathrm{N})$ in $\mathrm{CH}_{2} \mathrm{Cl}_{2}$, in the presence of $\mathrm{N}$-diisopropylethylamine (Hünig's base) and we obtained, after consumption of 4 ( 2 h, r.t.), a mixture of the cycloadducts $^{1} 6$ and 7 in $84 \%$ yield (2:3 ratio), along with traces of the heterobetaine 8 . Surprisingly, after $48 \mathrm{~h}$ reflux, the cyclocondensation product ${ }^{2} 8$ was obtained as the major component (49\%), accompanied by minor amounts of the cycloadduct $6(16 \%)$, as evidenced by ${ }^{\mathrm{l}} \mathrm{H} \mathrm{NMR}$.

During attempts to characterize 7, bidimensional t.l.c. experiments (silica gel, EtOAc/ $\mathrm{MeOH})$ revealed that the cycloadduct 7 was easily transformed into the heterobetaine 8 . Furthermore, when 7 was isolated and heated in $\mathrm{CH}_{2} \mathrm{Cl}_{2}$ the heterobetaine 8 was also formed. However, under the same conditions the cycloadduct 6 extensively decomposes.

When unsymmetrical dipolarophiles were used an analogous behaviour was found, thus reaction of 4 with acrylonitrile afforded the heterobetaine $9 \mathrm{a}$ as the only isolated product (86\%) when the reaction was refluxed for $20 \mathrm{~h}$. After the initial $15 \mathrm{~min}$., t.l.c. showed the reaction mixture to contain adducts similar to 6 and 7, together with 9a. With longer periods, one of the cycloadducts (highest $R_{f}$, analogous to 7 ) was seen to be transformed into $9 a$ as observed by bidimensional t.l.c.(silica gel, hexane: EtOAc, 1:1/ MeOH).

The scope of the process was tested with different Michael acceptors (Scheme 2) giving rise to mixtures of dihydroderivatives 9 and the fully aromatic compounds 10. Furthermore, heterobetaines 9 were extensively transformed to 10 after $3 \mathrm{~h}$ reflux in $\mathrm{CH}_{3} \mathrm{CN}$.

\footnotetext{
'The assigned structure of the major regioisomer 7 was established by ${ }^{1} \mathrm{H}$ NMR data on the basis of chemical shifts of the dihydropyridine moiety which show wellresolved signals for $\mathrm{H}_{4}-\mathrm{H}_{7}$. Similarly, the structure of the cycloadtuct 6 derived from ${ }^{1} \mathrm{H}$ NMR was identified as the endo-cycloadduct. Coupling constants between $\mathrm{H}_{3}$ and $\mathrm{H}_{3 .}(8 \mathrm{~Hz})$ as well as $\mathrm{H}_{3}$ and $\mathrm{H}_{2}(8 \mathrm{~Hz})$ are consistent with a cis disposition for these hydrogens. Full characterisation of 6 and 7 was unambigously established by irradiation of the protons.
}

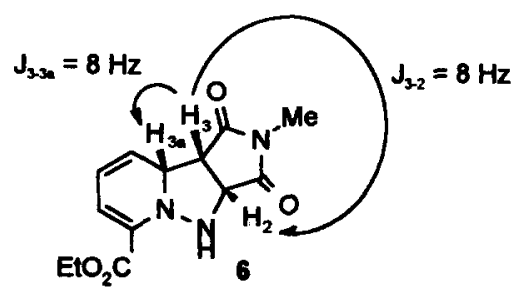




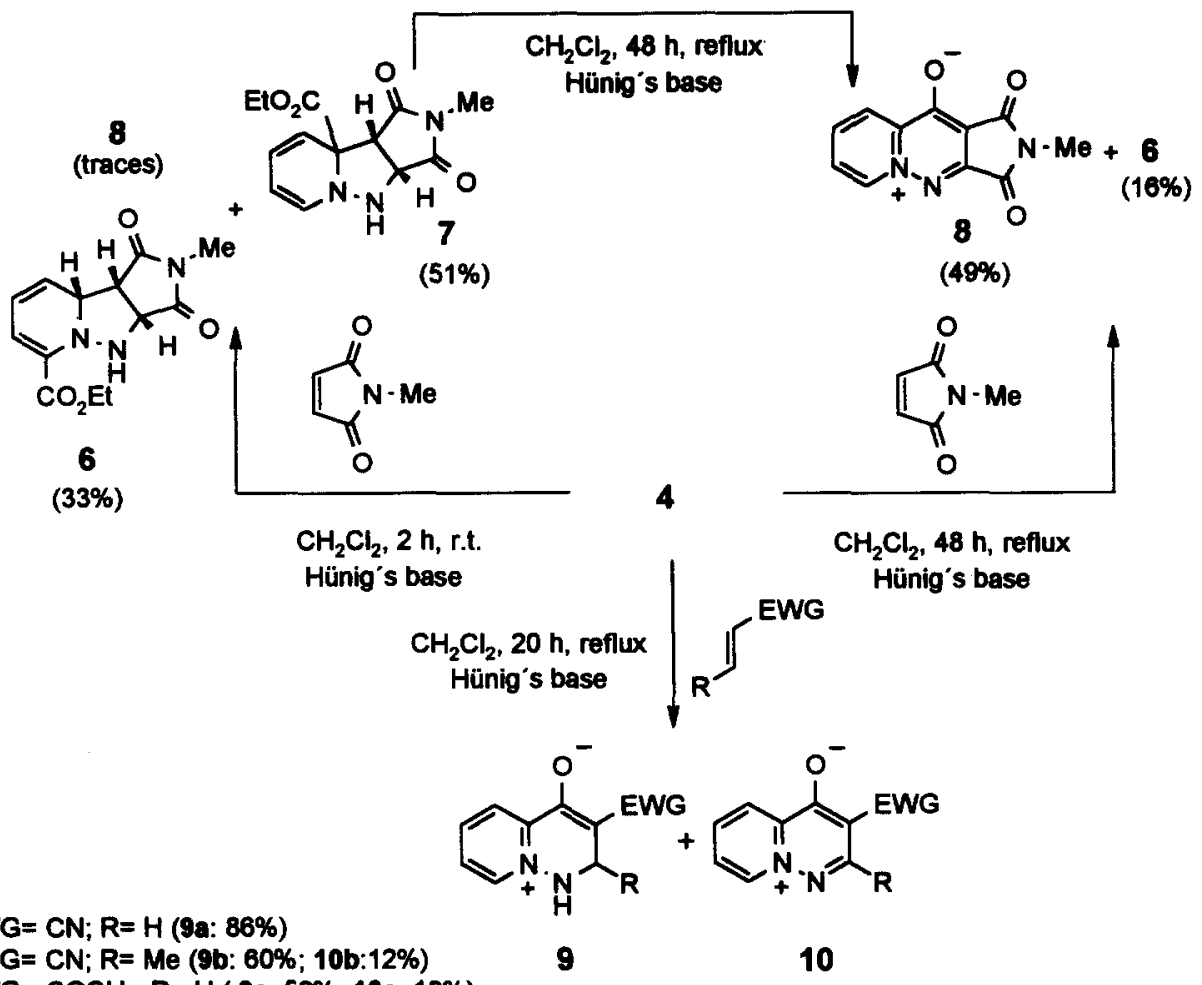

$E W G=C N ; R=\operatorname{Me}(9 b: 60 \% ; 10 b: 12 \%)$

$E W G=\mathrm{COCH}_{3} ; \mathrm{R}=\mathrm{H}$ ( 9c: $\left.52 \% ; 10 \mathrm{c}: 18 \%\right)$

$E W G=C N ; R=P h(10 d: 30 \%)$

$E W G=\mathrm{COCH}_{3} ; \mathrm{R}=\mathrm{Ph}(10 \mathrm{e}: 32 \%)$

Scheme 2

To our knowledge, this is the first evidence of a cycloadduct ring expansion process, leading to the formation of conjugated mesomeric betaines. No doubt, the steric hindrance of the regioisomer 11 would favour rearrangement to the more stable system 15, through a ringopening process in which the dihydropyridine moiety regains aromaticity. Although the evolution of regioisomer 12, is less clear, cycloreversion, oxidation or $\mathrm{N}-\mathrm{N}$ bond cleavage should be involved [18].

\footnotetext{
${ }^{2}$ General Procedure for the Preparation of Heterobetaines. To a solution of the salt $4(1 \mathrm{mmol})$ and the corresponding olefinic compound ( $1.1 \mathrm{mmol})$ in dry $\mathrm{CH}_{2} \mathrm{Cl}_{2}(10 \mathrm{~mL})$, N-ethyldisopropylamine $(2 \mathrm{mmol})$ was added dropwise. After refluxing the reaction mixture for 48 h or $20 \mathrm{~h}, 8$ and 9 were isolated by filtration and 10 were purified by chromatography (silica gel, acetone or acetone : EtOAc) from the filtrate. All new compounds described have satisfactory spectral and analytical data. For the compound 8: $\mathrm{mp}>300$ ${ }^{\circ} \mathrm{C}$ (DMF); IR (KBr) 1710, 1617, 1589, 1537, 1437, $1375 \mathrm{~cm}^{-1}$; ${ }^{1} \mathrm{H}$ NMR (DMSO-d $6,300 \mathrm{MHz}$ ) 9.39 (d, 1H, J=6.6 Hz), 8.71 (d, $1 \mathrm{H}$, $J=7.7 \mathrm{~Hz}$ ), 8.42 (t, $1 \mathrm{H}, J=7.7 \mathrm{~Hz}), 8.19-8.11(\mathrm{~m}, 1 \mathrm{H}), 2.98(\mathrm{~s}, 3 \mathrm{H}) ;{ }^{13} \mathrm{C}$ NMR (DMSO-d 6 , $\left.50 \mathrm{MHz}\right) 165.2,164.8,161.1,154.5$, $147.6,146.8,142.3,139.4,127.4,124.4,23.5 ; \mathrm{MS}(\mathrm{m} / \mathrm{z}) 229\left(\mathrm{M}^{+}, 55\right), 106(55), 78(100)$. Anal. Calcd for $\mathrm{C}_{11} \mathrm{H}_{7} \mathrm{~N}_{3} \mathrm{O}_{4}: \mathrm{C}, 57.65 ; \mathrm{H}$, $3.08 ; \mathrm{N}, 18.33$. Found: $\mathrm{C}, 57.59 ; \mathrm{H}, 3.29 ; \mathrm{N}, 17.98$.
} 


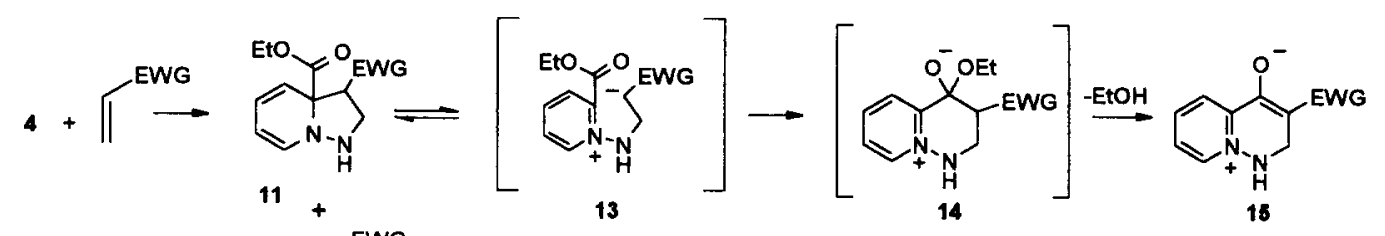<smiles>CCOC(=O)C1=CC=CC2C(C(C)(C)C)CNN12</smiles>

Scheme 3

A theoretical study to establish whether the reaction pathway from the cycloadduct 11 to the heterobetaine 15 involves the intermediate 13 (Scheme 3), as was the case for the reaction of 4 with heterocumulenes, or proceeds throughout a concerted mechanism, is under investigation using $a b$ initio techniques and the results will be the subject of a future report.

\section{Acknowledgements.}

We wish to express our thanks to the Comision Interministerial de Ciencia y Tecnología (CICYT, project PM97-004) and to the Ministerio de Educación y Ciencia for a grant to one of us (J.V.M).

\section{References}

[1] Ollis WD, Stanforth SP. Tetrahedron. 1985;41:2239-2329.

[2] Padwa A. in: 1,3-Dipolar Cycloaddition Chemistry, vol 2, eds. Taylor EC, Weissberger A. New York: John Wiley, 1984.

[3] Westphal, O; Jahn, K; Heffe, WE. Arch. Pharm. 1961;294:37-45.

[4] Matia MP, Garcia-Navio JL, Vaquero JJ, Alvarez-Builla J. J. Heterocyclic Chem. 1990;27:661-665.

[5] Matia MP, Ezquerra J, Sanchez-Ferrando F, Garcia-Navio J, Vaquero JJ, Alvarez-Builla J. Tetrahedron. 1991;47:7329-7342.

[6] Matia MP, Ezquerra J, Garcia-Navio JL, Vaquero JJ, Alvarez-Builla J. Tetrahedron Lett. 1991;32:7575-7578.

[7] Hajós G, Messmer A, Bátori S, Riedl Z. Bull. Soc. Chem. Belg. 1992;101:597-607.

[8] Hajós G, Riedl Z, Gács-Baitz E, Messmer A. Tetrahedron. 1992;48:8459-8464.

[9] Matia MP, Garcia-Navio JL, Vaquero JJ, Alvarez-Builla J. Liebigs Ann. Chem. 1992:777-779.

[10] Santiesteban I, Siro JG, Vaquero JJ, Garcia-Navio JL, Alvarez-Builla J, Castaño O. J. Org. Chem. 1995;60:5667-5672.

[11] Diaz A, Matia MP, Garcia-Navio JL, Vaquero JJ, Alvarez-Builla J. J. Org. Chem. 1994;59:8294-8296.

[12] Bátori S, Juhász-Riedl Zs, Sandor P, Messmer A. J. Heterocyclic Chem. 1986;23:375-380.

[13] Bátori S, Messmer A. J. Heterocyclic Chem. 1988;25:437-444.

[14] Bátori S, Hajós G, Sándor P, Messmer A. J. Org. Chem. 1989;54:3062-3068.

[15] Bátori S, Messmer A. J. Heterocyclic Chem. 1990;27:1673-1680.

[16] Cuadro AM, Valenciano J, Vaquero JJ, Garcia-Navio JL, Alvarez-Builla J. Tetrahedron. 1993;49:3185-3192.

[17] Boekelheide V, Feddoruk N. J. Org. Chem. 1968;33:2062-2064.

[18] Katritzky AR, Lam JN. Heterocycles. 1992;33:1011-1049. 